\title{
Farmers' Knowledge Is the Basis for Local Level Agro-Forestry Management: The Case of Lemo Woreda in Hadiya Zone, Ethiopia
}

\author{
Yohannes Horamo ${ }^{1,2 *}$, Munyaradzi Chitakira ${ }^{1 *}$ and Kowiyou Yessoufou ${ }^{3 *}$ \\ ${ }^{1}$ Department of Environmental Science, University of South Africa, Johannesburg, South Africa, ${ }^{2}$ Department of Natural \\ Resources Management, Wachemo University, Hosaena, Ethiopia, ${ }^{3}$ Department of Geography, Environmental Management \\ and Energy Studies, University of Johannesburg, Johannesburg, South Africa
}

OPEN ACCESS

Edited by:

Emmanuel Donkor. Humboldt University of

Berlin, Germany

Reviewed by:

Faizal Adams,

Kwame Nkrumah University of Science and Technology, Ghana

Yong Sebastian Nyam,

University of the Free State,

South Africa

*Correspondence:

Munyaradzi Chitakira

chitam1@unisa.ac.za

Yohannes Horamo

58550763@mylife.unisa.ac.za

Kowiyou Yessoufou

kowiyouy@uj.ac.za

Specialty section:

This article was submitted to

Climate-Smart Food Systems,

a section of the journal

Frontiers in Sustainable Food Systems

Received: 09 July 2021

Accepted: 03 September 2021

Published: 05 October 2021

Citation:

Horamo Y, Chitakira M and

Yessoufou K (2021) Farmers'

Knowledge Is the Basis for Local Level Agro-Forestry Management: The

Case of Lemo Woreda in Hadiya

Zone, Ethiopia.

Front. Sustain. Food Syst. 5:739061.

doi: 10.3389/fsufs.2021.739061
This research was designed to investigate the hypothesis that farmers practising traditional agro-forestry which dates back for centuries have accumulated immense knowledge of agro-forestry, which can be captured and incorporated into formal development programmes to improve it. Farmers' knowledge must be documented, valued and integrated in order to maximise its importance for planning and decision-making. This research aimed to investigate and document farmers' knowledge of managing agro-forestry and the contribution to sustainable management of natural resources. Accordingly, questionnaire surveys were conducted in six villages from three peasant associations. In total, 73 households were selected for interview and the data collected were analysed using SPSS (Statistical Package for Social Science) version 26. The findings revealed tree species that contribute to crop yield improvement and the important role agro-forestry trees play with regard to soil fertility. Farmers' strategies to associate trees and shrubs in their farmlands were revealed. Tree species with a negative effect on crop yields were identified and recorded. Farmers reported and ranked in the order of importance, opportunities and constraints in the management of agroforestry. Farmers' accumulated knowledge of tree-crop and tree-animal interactions, the role of trees in soil fertility, crop and livestock improvement, revealed in the study can significantly enhance the stainability of agriculture. If local knowledge is not documented, it remains largely inaccessible to development workers seeking solutions to locally defined problems.

Keywords: agro-forestry, farmers' knowledge, tree-animal interaction, tree-crop interaction, crop yield

\section{INTRODUCTION}

Local farmers are the inhabitants of a particular geographic rural area; they live by rearing crops and animals. They have developed over centuries a culture and belief system which is distinct from the so-called modern international system of knowledge (Njiraine et al., 2010). Through this cuture and belief system, local farmers have accumulated tremendous indigenous knowledge about their surrounding natural resources, which has enabled them to survive often harsh environmental conditions (Payyappallimana and Koike, 2010). Knowledge is regarded as the body of mental inferences and conclusions that people build 
from different elements of information and which allows them to take informed actions in a given context (Leeuwis, 2013). It is an output of learning, reasoning and perceptions, and it forms the basis for predictions of future events (Cheveau et al., 2008). Knowledge, especially traditional knowledge is not static but dynamic since it has to evolve over time in response to new challenges.

The new challenges humanity is now facing is environmental degradation due mainly to exponential human population growth that put unprecendented pressure on natural capital. Other modern-day challenges include over-exploitation of natural resources, climate change, alien invasive species, deforestation and pollution (De Groot et al., 2010; Sjögren, 2015). The negative impacts of these environmental challenges are particularly felt by local population in rural areas because of natural predispositions driven by poverty, poor education and collapsing medicinal system, and more critically food insecurity. In response to food insecurity, modern input to farming such as mineral fertilisers have been introduced to traditional farming (Larson et al., 2016). However, the use of mineral fertilisers is declining as they are increasingly beyond the means of most small-scale farmers (Chowdhury et al., 2009). For example, Meijer et al. (2015) reported that one of the major constraints to crop production faced by smallholder subsistence farmers is the inadequate supply of nutrients. Even fertilisers, if used excessively and aggressively, may pose additional environmental and health problems, e.g., water pollution.

In this context, some suggested that the investigation of traditional knowledge related to farming, e.g., agro-forestry, in search of a way to improve traditional farming practises is the way forward in rural African context (Brown et al., 2018). Previous research tended to focus on determining the appropriate type of agro-forestry needed to obtain the best yields for particular soil types and specific agro-ecological locations. This approach emphasised the use of external inputs and expensive technologies (Larson et al., 2016) and often disregarded traditional farmers' knowledge and the resources at their disposal. For example, several development projects and policies have collapsed because of a failure to understand and integrate local knowledge, and how this influences the way farmers manage natural resources (Musinguzi et al., 2015). This prompts the call for research to gradually shift towards an approach based on integrated traditional agro-forestry practises into improvement strategy of crop production. This approach requires a thorough scientific understanding of the underlying biological processes of integrated agro-forestry management and aims to promote options that make the best use of locally available knowledge and inputs (Dawoe et al., 2012).

Sustaining soil fertility through agro-forestry has become a major issue for agricultural research and development in subSaharan Africa (Dagar et al., 2013; Sjögren, 2015).

Agro-forestry, as a scientific discipline is relatively recent, although cultivating trees and agricultural crops in intimate combination with one another on the same farm is an ancient practise used by farmers throughout the world (Kindeya, 2004; De Groot et al., 2010; Dagar et al., 2013; Sjögren, 2015). During the past few decades, interest in agro-forestry has increased substantially. Agroforestry presents numerous benefits that need to be preserved and increased. For example, agroforestry sysetms control runoff and soil erosion, thus preventing the loss of water and soil and nutrients that crops needs for productivity.

They can maintain soil organic matter and biological activity at levels satisfactory for soil fertility. This depends on an adequate proportion of trees in the system-normally at least $20 \%$ crown cover of trees to maintain organic matter over systems as a whole. They can maintain more favourable soil physical properties than agriculture, through organic matter maintenance and the effects of tree roots. They can lead to more closed nutrient cycling than agriculture and hence to more efficient use of nutrients. This is true to an impressive degree for forest garden/farming systems. They can cheque the development of soil toxicities, or reduce exiting toxicities-both soil acidification and salinization can be checked and trees can be employed in the reclamation of polluted soils. They utilise solar energy more efficiently than monocultural systems different height plants, leaf shapes and alignments all contribute. They can lead to reduced insect pests and associated diseases. They can be employed to reclaim eroded and degraded land. Agro forestry can augment soil water availability to land use systems. In dry regions, though, competition between trees and crops is a major problem. Nitrogen-fixing trees and shrubs can substantially increase nitrogen inputs to agro forestry systems. Trees can probably increase nutrient inputs to agro forestry systems by retrieval from lower soil horizons and weathering rock. The decomposition of tree and pruning can substantially contribute to maintenance of soil fertility. The addition of highquality tree prunings leads to large increase in crop yields. The release of nutrients from the decomposition of tree residues can be synchronised with the requirements for nutrient uptake of associated crops. While different trees and crops will all have different requirement, and there will always be some imbalance, the addition of high quality prunings to the soil at the time of crop planting usually leads to a good degree of synchrony between nutrient release and demand. In the maintenance of soil fertility under agro forestry, the role of roots is at least as important as that of above-ground biomass. Agro forestry can provide a more diverse farm economy and stimulate the whole rural economy, leading to more stable farms and communities. Economics risks are reduced when systems produce multiple products.

Unfortunately, agro-forestry activities are now declining in many parts of Sub-Saharan Africa (SSA) (Alemayehu et al., 2009) due to challenges leading farmers to either abandon entirely the traditional agro-forestry using natural fallow to restore soil fertility or to leave land fallow for long enough for it to be effective (Chitakira and Torquebiau, 2010).

The present study sought to understand how the farmers in the Woreda have managed the complex nature of the interactions between agricultural production and tree cultivation in order to appreciate the role of farmers knowledge. The study was designed with the intention to study and document farmers' knowledge of managing agro-forestry and bridge their overall contribution to the future development of agro-forestry and sustainable agriculture. The research questions considered include: (1) What is the role of the farmers' knowledge in the management of sustainable agriculture and agro-forestry? (2) What are the 

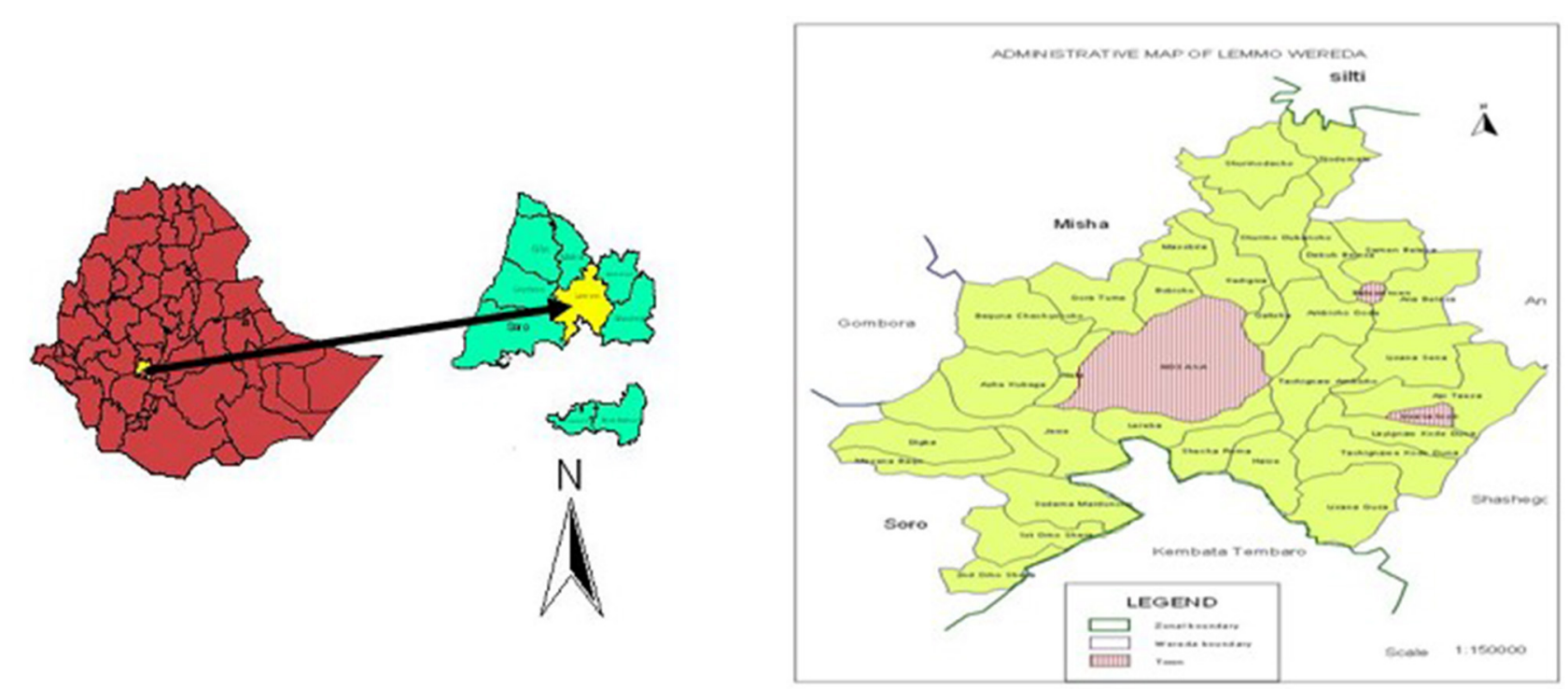

FIGURE 1 | Location of Hadiya zone and study area Lemo Woreda in Ethiopia.

opportunities and challenges for managing the existing agroforestry in the study area?

\section{METHODS AND MATERIALS \\ Description of the Study Area}

The study area (Lemo Woreda) is situated in Hadiya Zone in Southern Nations Nationalities and Peoples Regional State (SNNPRS) (Figure 1). The study area geographically lies between Latitude $07^{0} 41^{\prime} \mathrm{N}$ and Longitude $037^{0} 31^{\prime} \mathrm{E}$. Topography of the study area is rugged high land and hilly areas with a slope range of 2 to $30 \%$. Generally, the terrain is mountainous, undulating and very much prone to soil erosion. Hosanna city in Lemo Woreda is the capital of the Hadiya zone. It is situated $230 \mathrm{~km}$ south of Addis Ababa, the capital of Ethiopia.

The soils in the study area are intensively cultivated and greatly degraded through erosion. Measures are being taken by the agriculture extension officers, individual farmers, interested groups and NGO's (Non-Governmental Organisations) to address the soil erosion challenge and loss of soil fertility. This is done through creating awareness and training of farmers on how to control soil loss by constructing physical structures supported by means to maintain soil fertility.

The Woreda is found in "Woina Dega" agro-climatic zone with altitudinal range of 1950-2400 m.a.s.l. It has a cool temperature range of $15-18^{\circ} \mathrm{C}$ and an average rainfall of $1150 \mathrm{~mm}$. The rivers and seasonal streams in the Woreda supply water for both drinking and sanitation purposes, and one of the rivers, Bilate river, is used for small scale irrigation. The major perennial rivers that flow permanently throughout the year are, Bilate and Guder which are flow into Lake Abaya on the rift valley.

In the Woreda, all of the natural vegetation and grazing lands have almost been converted into cultivated land. What remains in the area are the retained trees that are scattered in all land-use types. Farmers are already accustomed to planting some tree species to replace the former natural vegetation, to meet the demands for wood, construction and fuel. The socio economic factors may be the main reasons for diminishing forest resources (LWOAaRD (Lemo Woreda Office of Agriculture Rural Development),, 2012). Whereas, in the study areas farmers have been developing agricultural systems, domesticating animals, breeding new crop varieties and constructing irrigation systems throughout the centuries without the aid of formalised scientific approaches and agricultural extension systems (Pirker et al., 2012). The dominant land-use types in the Woreda are sedentary mixed farming with the cultivated land accounting for $89 \%$ of the total land area (LWOAaRD (Lemo Woreda Office of Agriculture Rural Development)., 2012). This indicates that there is great pressure on land. The area practises mixed farming, with complete integration of trees, crop production and animal husbandry. Animals provide food, draught power, manure for crops, and fuel. Crop residues are used as feed for animals.

\section{Data Collection}

Three Peasant Associations (PAs) were identified by purposive sampling with the assistance of local extension officers in the Woreda for the study. The selection was based on the existence of traditional agro-forestry and on accessibility of the PA. Three villages from each peasant association were selected for this study. The same number of participants was chosen from each PA. The sample size for this study was computed using kurtosis formula i.e., $n=\mathrm{z}^{2} \mathrm{qpN} / \mathrm{e}^{2}(\mathrm{~N}-1)+\mathrm{z}^{2} \mathrm{pq}$ Where: $p=$ Allowable error and confidence interval of (z) $95 \%, N=$ total number of households or population, $n=$ sample size from total households 
and $z=$ confidence interval of $95 \%$ from $z$-table. From each PA, 73 households were selected for questionnaire interviews.

One could assume that farmers' knowledge in managing agroforestry depends on the socioeconomic status of the farmers. The list of households was written down on a paper. Individual households were selected for study from each PA by means of simple random sampling, based on the list of households. Data collection was achieved by means of 6 enumerators i.e., 2 per PA who were trained before being assigned to collect data. The enumerators had to have a minimum of a diploma in natural resources management or related fields.

Data collection was conducted over a period of two months using pre-tested and semi-structured questionnaires. Questionnaires were designed to gather farmers' knowledge on managing agro-forestry and the implication for each household. The questionnaire was pre-tested to ensure it was able to collect the data it was intended to collect and to make adjustments as appropriate. The researchers also made observation in the area during interviews to supplement data obtained from the questionnaire interviews.

\section{Data Analysis}

Data collected were coded and then analysed using the Statistical Package for Social Sciences (SPSS) version 26. The data were summarised and descriptive statistical analysis (including frequencies, percentages, and ranks) was conducted and results interpreted accordingly.

\section{RESULTS AND DISCUSSION}

\section{Agro-Ecological and Socio-Economic Conditions of the Study Area}

The ecological or biophysical and socio-economic conditions of the study area were surveyed and are summarised in Tables 1, 2. The study locations were characterised by the farmers themselves with the the research team playing a facilitation role. Tables 1, 2 show biophysical characteristics and land use types relating to tree, crop and animal production. The results compare fairly well with the findings of Glover et al. (2013). The land use land cover types reveal that cultivated land alone accounts for $78.5 \%$ of the total land. This implies that the study area should have to focus on tree planting on the farms to increase tree cover, as noted by Arnold and Dewees (2014). Tree planting on farmland could mean a loss of agricultural income on the short-term but has a considerable economic gain in the long run (Rahman et al., 2016).

\section{Farmers' Knowledge in Managing Agro-Forestry \\ Tree-Crop Interactions}

The study revealed local farmers' knowledge about tree and shrub species that contribute positively to crop yield and/or animal yield and those that potentially result in decrease of crop yield/animal yield. These findings are in agreement with findings by Glover et al. (2013) that trees and shrubs are the characteristic features in traditional agro-forestry and that trees interact through complementary, supplementary and competitive forms when they grow in proximity to crops and/or to each other. An understanding of the nature of interactions between trees and crops is of major importance in determining tree-management strategies of agro-forestry because the success of agro-forestry depends on the management of such component interactions (Schroth, 1995; Dagar et al., 2013; Yakob et al., 2014).

\section{Positive Attributes of Trees}

There was a wide awarenness among farmers that without manure and/or crop residue additions soil fertility is very much reduced, particularly in the absence of improved tree fallowing and continuous farming. The threat of food insecurity was revealed as a challenge in the area because of the declining trends of soil fertility and forest destruction. All respondents agreed that a decrease in crop-yield is the indicator of a decrease in soilfertility status. Generally, the local farmers perceived brown soils and as fertile soil and grey coloured soil as poor in fertility and not good for crop production. The farmers perceived that fertile soils were found on flat land where silt deposition takes place with gradient change from the rugged upland to the lowlying areas.

The respondents expressed knowledge of which tree species contribute to improvement of soil fertility status. Knowledge of which part of the tree/shrubs decompose faster and change to soil was revealed. Leaves were mentioned as fast-decomposing tree part followed by roots. This study confirmed that farmers have manipulated and helped the slow evolution of agro-forestry to fit the environment and their needsThe respondents were quick to tell which tree species have a potential for improving crop yield, which ones decompose fast and supply large amount of litter. For instance, the farmers reported crops under managed Acacia abyssinica as having a good potential to improve cropyield. The findings were consistent with the observations by Ponge (2013) that crop yield is better around tree stumps than elsewhere in fields. Similarly, Bishaw et al. (2013) reported that farmers experience yield improvements when crops were planted with multipurpose trees. A study by Goldammer (2013) revealed a yield increment of sorghum and maize associated with Acacia albida. This study confirms the findings in a study by Cerdán et al. (2012) that farmers had a good understanding of how and when leaf material is decomposed and release nutrients into the soil substrate.

Respondents in this study indicated that the order of importance with regard to soil fertility as: Erthrina abyssinica $>$ Vernonia auriculifera $>$ Cordia africana $>$ Adathoda schemperiana $>$ Croton macrostachys $>$ Ficus sur $>$ Vernonia amygdalina. There exists considerable knowledge of agroforestry including selection of species for incorporation into farmlands. Trees incorporated or retained for treecrop combinationshave positive attributes as regards yield improvement (Table 3). It was found that some individuals were not interested in incorporating Acacia species into their farms, mainly because of the thorny nature of the species, which causes difficulties during agricultural activities.

The respondents listed seven indigenous tree/shrub species that they perceived to improve crop yield (Table 3). Crops grown under these trees are believed to grow vigorously. These tree species are characterised by light crown and small crown dimension which minimise light competition with companion 
TABLE 1 | Biophysical information.

\begin{tabular}{|c|c|c|c|c|}
\hline \multirow[t]{2}{*}{ Attributes } & \multirow[t]{2}{*}{ Lemo woreda } & \multicolumn{3}{|c|}{ Peasant associations } \\
\hline & & Masbira & Shecha & Lissana-senna \\
\hline Altitude (m.a.s.l) & $1950-2400$ & $2140-2360$ & 1950-2200 & $2100-2240$ \\
\hline Rainfall $\left(\mathrm{mm} \mathrm{a}^{-1}\right)$ & $900-1400$ & $900-1400$ & $900-1400$ & $900-1400$ \\
\hline Temperature $\left({ }^{\circ} \mathrm{C}\right)$ & $15-18^{0} \mathrm{C}$ & $15-18^{0} \mathrm{C}$ & $15-18^{0} \mathrm{C}$ & $15-18^{\circ} \mathrm{C}$ \\
\hline Topography (slope \%) & $5-54 \%$ & $4-15 \%$ & $2-15 \%$ & $2-16 \%$ \\
\hline \multirow[t]{2}{*}{ Location } & & $07^{\circ} 35^{\prime} \mathrm{N}$ & $7^{0} 29^{\prime} \mathrm{N}$ & $07^{0} 33^{\prime} \mathrm{N}$ \\
\hline & & $037^{0} 55^{\prime} \mathrm{E}$ & $037^{0} 52^{\prime} \mathrm{E}$ & $037^{0} 55^{\prime} \mathrm{E}$ \\
\hline Average distance from Hossana (Km) & - & 11 & 9 & 12 \\
\hline
\end{tabular}

Source: Survey results.

TABLE 2 | Land use types.

\begin{tabular}{|c|c|c|c|c|c|c|c|c|}
\hline \multirow[t]{3}{*}{ Land Use } & \multicolumn{2}{|c|}{ Lemo woreda } & \multicolumn{6}{|c|}{ Peasant associations } \\
\hline & \multirow[b]{2}{*}{ Area (ha) } & \multirow[b]{2}{*}{ Percent } & \multicolumn{2}{|c|}{ Masbira } & \multicolumn{2}{|c|}{ Shacha } & \multicolumn{2}{|c|}{ Lissana-senna } \\
\hline & & & Area (ha) & Percent & Area (ha) & Percent & Area (ha) & Percent \\
\hline Cultivated land & 27,441 & 78.5 & 545 & 78.4 & 512 & 64 & 907 & 63.3 \\
\hline - Annual crops & 23,697 & 67.8 & 497 & 71.4 & 392 & 49 & 698 & 48.7 \\
\hline - Perennial Crops & 3,744 & 10.7 & 48 & 7 & 120 & 15 & 209 & 14.6 \\
\hline Wood lot, bush\& shrub land & 2,418 & 7 & 50 & 7.1 & - & - & 16 & 1.1 \\
\hline Area closure & 349 & 1 & 5 & 0.7 & 61 & 7.6 & 275 & 19.2 \\
\hline Grazing land & 1,079 & 3 & 92 & 13.2 & 48 & 6 & 35 & 2.4 \\
\hline Others & 3,686 & 10.5 & 4 & 0.6 & 179 & 22.4 & 201 & 14 \\
\hline Total & 34,973 & 100 & 696 & 100 & 800 & 100 & 1,434 & 100 \\
\hline
\end{tabular}

Source: Survey results.

crops. The tree species identified as having positive attributes for crop yield improvement include Grevillea robusta, Acacia abyssinica, Millettia ferruginea, Acacia saligna, Ekbergia capensis and Ricinus communis.

This research revealed a considerable wealth of local knowledge about quality of leaf litter. Considerable knowledge was found on litter decomposition and characterisation in terms of early-decomposing and late- or slow-decomposing litter. It was mentioned that rates of of decomposition of litter from different trees and shrubs were variable. Crop yield improvement resulting from tree or shrub litter decomposition was wellappreciated by respondents. There was a general understanding among the locals regarding the correlation between crop yield improvement and litter decomposition. Farmers also appreciated the significant role that soil microorganisms play in litter decomposition. During the discussions the most frequently mentioned tree and shrub species with early-decomposing litter are in the following order: E. abyssinica $>V$. auriculifera $>C$. africana $>$ A. schemperiana $>$ C. macrostachyus $>$ F. sur $>V$. amygdalina (Table 3). Table 4 illustrates the criteria used by the local farmers to characterise the trees on their farmland.

Farmers in this study confirmed having recognised the soilfertility status of their farmland declining. The respondents indicated that the soil had become poorer in terms of fertility and hardly supports crop growth beside weeds. The farmers in the area could identify fertile soils by looking at the colour: fertile soil is "bunama" in colour or "wet sand" while poor soil is "white or ash." This finding is consistent with a study conducted in Zimbabwe by Chuma et al. (2000) which showed that farmers can explain soil fertility decline to an extent of predicting that no yield could be obtained in certain soils without applying fertilisers. A study by Nandwa et al. (2000) reported that the farmers considered decline in soil fertility as the main constraint to crop production and productivity. Thus, several studies have confirmed the capability of farmers to assess the suitability of soils for crop production. Farmers have developed various techniques to improve or maintain soil fertility (Munyua and Stilwell, 2013). A study by Elias (2000) showed that there was a wide use of leaf litter by resource-poor farmers to manage soil fertility, owing to the prevalence of bushes near farms. A study by Munyua and Stilwell (2013) showed that Faidherbia albida sheds its leaves, the roots draw nutrients and the tree fixes nitrogen to enrich the soil and improve crop yields and also reported the value of C. africana trees to soil enrichment.

\section{Adverse Effects of Woody Plants on Crops}

Interviews in this study revealed the negative impacts that trees and shrubs have on crops. Species mentioned as having notable negative effects on crop yields are Eucalyptus globules and Eucalyptus camaldulensis. These species are not allowed 
TABLE 3 | Tree species for soil fertility.

\begin{tabular}{|c|c|c|c|c|c|c|c|c|c|c|}
\hline $\mathbf{S} / \mathbf{N}$ & Tree species & 1 & 2 & 3 & 4 & 5 & 6 & 7 & Point & Rank \\
\hline 1 & Erthrina abyssinica (Er) & & Er & Er & $\mathrm{Er}$ & Er & Er & Er & 6 & 1 \\
\hline 2 & Ficus sur (Fi) & & & Co & Co & Ve1 & $\mathrm{Fi}$ & As & 1 & 6 \\
\hline 3 & Cordia africana (Co) & & & & Co & Ve1 & Co & As & 4 & 3 \\
\hline 4 & Croton macrstachyus (Cr) & & & & & Ve1 & $\mathrm{Cr}$ & $\mathrm{Cr}$ & 2 & 5 \\
\hline 5 & Vernonia auriculifera (Ve1) & & & & & & Ve1 & Ve1 & 5 & 2 \\
\hline 6 & Vernonia amygdalina (Ve2) & & & & & & & As & 0 & 7 \\
\hline 7 & Adathoda schemperiana (As) & & & & & & & & 3 & 4 \\
\hline
\end{tabular}

Source: Survey results.

\begin{tabular}{llcc}
\hline \multicolumn{2}{l}{ TABLE $\mathbf{4}$ | } & Farmers strategies to characterise trees and shrubs in their farmlands. \\
\hline S/N & Criteria & $\begin{array}{c}\text { \% of respondents } \\
(\boldsymbol{n}=\mathbf{7 3})\end{array}$ & $\boldsymbol{R a n k}$ \\
\hline 1 & Palatability & $62(83.5 \%)$ & 3 \\
2 & Soil fertility/ Decomposability & $69(94.5 \%)$ & 1 \\
3 & Branch volume & $42(57.5 \%)$ & 5 \\
4 & Construction wood & $63(86.3 \%)$ & 2 \\
5 & Shade & $55(75.3 \%)$ & 4 \\
6 & Unpalatable & $20(27.4 \%)$ & 7 \\
7 & Densely grown & $30(41 \%)$ & 6
\end{tabular}

Source: Survey results.

to grow in crop fields due to their perceived negative effects. The adverse effects were explained in terms of competition, killing of other vegetation and late or slow decomposition. Some participants expressed that the land on which Eucalyptus roots existed was no longer good agricultural land as it becomes dry. The roots of E. globules and E. camaldulensis were perceived to have a negative effect to crops, owing to severe competition for nutrients and water. The allelochemical (acidic) from E. globulus tends to kill the vegetation beneath the canopies and around the E. globulus. With regard to late decomposition Eucalyptus was clearly distinguished. The leaves and branches of E. globulus and E. camaldulensis were reported to remain on the ground undecomposedfor several months or years. E. globulus was ranked by the respondents as the top-most in having an adverse influence on crops. Despite knowledge of the negative effect of Eucalyptus on crops, the farmers still planted Eucalyptus close to their farmlands.

In this study E. globules and E. camaldulensis were commonly identified to have a negative influence on crop yield. It was clearly noted that Eucalyptus species dry up the land and compete with crops for nutrients and water. The respondents' opinions in this study confirm studies conducted in Ethiopia by Kidanu et al. (2005) and Nyssen et al. (2009) which showed that competition for water, soil nutrients and allelopathic effects between Eucalyptus and annual crops may occur close to the tree rows and that tree species such as Eucalyptus spp., Cupressus lusitanica, Olea europaea, Podocarpus falcatus, Juniperus excelsa have such effects. In a study by Tafere and Nigussie (2018) in
Sidama, both the farmers and extension workers confirmed that the planting of Eucalyptus affected adjacent crops while Tafere and Nigussie (2018) established that Eucalyptus takes up a high amount of water and nutrients from the soil so that it might affect crops planted next to it. A study in Southern Ethiopia by Tesfaye (2005) also revealed that E. camaldulensis was perceived as having competitive effects and and the farmers would not allow it to grow together with crops. Thus the findings in the present study are in line with findings from related studies.

\section{Tree-Animal Interactions}

Livestock play an important role in the livelihoods of the community of the study area. Farmers are highly concerned about the availability of fodder. As such, local farmers utilise woody plants to supplement the meagre supply of fodder for livestock (Table 5). This study showed that farmers' preferences for fodder and shrub species were influenced by the feeding preference of their livestock or the palatability of livestock browse. It was reported that livestock were fed from trees and shrubs mainly in the dry season when rangelands will not be having sufficient grass (Table 5). Woody species commonly used for fodder in the area during the dry season are Sesbamia sesbania, Persea americana, Erythrina abyssinica, Chamcytesus palmensis, Olea eurropaea, Verninia amygdalina, Enset ventricosum, Adathoda schemperiana, and Grevillea robusta.

Table 5 shows a list of fodder trees/shrubs. The order of browsing preference starting with the most preferred was: E. ventricosum $>A$. Schemperiana $>V$. amygdalina> O. eurropaea $>$ S. sesbania $>$ C. palmensis $>$ G. robusta $>P$. americana $>$ E. abyssinica. The leaves, new shoots, barks, fruits, pods or flowers were the tree parts used for fodder. Farmers indicated some order in preference in the use of tree or shrub parts for fodder. A general pattern or order of preferences derived from the farmers' responses was: older leaves $>$ new shoot $>$ bark > fruit/pods > flowers. Trees were identified as "most palatable" through to "not palatable" based on the preferences of the livestock.

It was also noted in the study area that there exists considerable knowledge on the adverse effects of trees/shrubs on animal health. For example, a leaf of Agave sisalina is considered very dangerous for livestock mainly due to its hard fibre which is difficult to digest and is capable of blocking the oesophagus. 
TABLE 5 | Trees and Shrubs used for Fodder and preference ranking.

\begin{tabular}{llcc}
\hline S/N & $\begin{array}{l}\text { Tree / } \\
\text { shrub species }\end{array}$ & $\begin{array}{c}\text { Percentage of respondents } \\
(\boldsymbol{n}=\mathbf{7 3})\end{array}$ & Ranking \\
\hline 1 & Sesbamia sesbania & $34(46 \%)$ & 5 \\
2 & Persea americana & $24(33 \%)$ & 8 \\
3 & Erythrina abyssinica & $20(27 \%)$ & 9 \\
4 & Chamcytesus & $31(43 \%)$ & 6 \\
& palmensis & $43(59 \%)$ & 4 \\
5 & Olea europaea & $56(77 \%)$ & 3 \\
7 & Verninia amygdalina & $71(97 \%)$ & 1 \\
8 & Enset ventricosum & $58(80 \%)$ & 2 \\
9 & Adathoda & & 7 \\
\hline
\end{tabular}

Source: Survey results.

TABLE 6 | Main Constraints in agro-forestry management.

\begin{tabular}{llll}
\hline S/N & Challenges & $\begin{array}{c}\text { Percentage of respondents } \\
(\boldsymbol{n}=\mathbf{7 3})\end{array}$ & Rank \\
\hline 1 & Shortage of land & $69(94 \%)$ & 2 \\
2 & Free grazing & $70(96 \%)$ & 1 \\
3 & Drought & $63(86 \%)$ & 3 \\
4 & Shortage of labour & $50(68 \%)$ & 5 \\
5 & Shortage of water & $53(73 \%)$ & 4 \\
6 & Shortage of seedling & $45(61 \%)$ & 6 \\
\hline
\end{tabular}

Source: Survey results.

R. Communis has also been mentioned as being involved in the bloating of livestock stomachs and in causing illness. When leaves of $A$. abyssinica are fed to goats during the dry season, they may cause sickness. Other uses of local trees such as fumigation of storage of some animal products like milk using O. europaea were highlighted. This result confirms the existence of indegenous knowledge technologies in the communities appropriate to the needs of farmers (Agrawal, 1995). Rural people also possess knowledge regarding the various animal rearing practises i.e., which trees and shrubs are toxic to the animals and which can be used for medicine, how to cure diseases and how to maintain animals in good health. In the study area, farmers use leaves of Allophylus abyssinica and Calpurnea aurea to cure their animals, O. europaea and V. amygdalina were used by farmers to fumigate and clean milk and local beer "tella" pots to ensure good taste, and smell. This observation is in line with the report by Yirga (2010).

\section{Opportunities and Challenges to Agro-Forestry}

Constraints experienced in the management of agro-forestry were mainly free grazing (96\%), shortage of land (94\%), drought $(86 \%)$, water scarcity (73\%), shortage of labour $(68 \%)$ and shortage of seedlings (61\%) (Table 6). Constraints that were mentioned in the management of agro-forestry nursery activities
TABLE 7 | Constraints in Agro-forestry nurseries.

\begin{tabular}{|c|c|c|c|c|}
\hline $\mathrm{S} / \mathrm{N}$ & Constraints & \multicolumn{2}{|c|}{$\begin{array}{l}\text { Percentage of respondents } \\
\qquad(n=73)\end{array}$} & Rank \\
\hline 1 & Knowledge limitations & \multicolumn{2}{|c|}{$50(68 \%)$} & 5 \\
\hline 2 & Pre sowing treatment & \multicolumn{2}{|c|}{$54(74 \%)$} & 4 \\
\hline 3 & Polyethene tube & \multicolumn{2}{|c|}{ 61(83\%) } & 2 \\
\hline 4 & Labour shortage & \multicolumn{2}{|c|}{$41(56 \%)$} & 6 \\
\hline 5 & Shortage of water & \multicolumn{2}{|c|}{ 64(88\%) } & 1 \\
\hline 6 & Seed shortage & \multicolumn{2}{|c|}{$56(77 \%)$} & 3 \\
\hline 7 & Pest and disease & \multicolumn{2}{|c|}{$4(5 \%)$} & 7 \\
\hline \multicolumn{5}{|c|}{ Source: Survey results. } \\
\hline \multicolumn{5}{|c|}{ TABLE 8 | Tree management decision. } \\
\hline $\mathrm{S} / \mathrm{N}$ & $\begin{array}{l}\text { Tree/ shrub } \\
\text { species }\end{array}$ & Men & Women & Both \\
\hline 1 & Acacia abyssinica & $37(50 \%)$ & $15(20 \%)$ & $21(30 \%)$ \\
\hline 2 & Cordia africana & $55(75 \%)$ & $15(20 \%)$ & $3(4 \%)$ \\
\hline 3 & $\begin{array}{l}\text { Croton } \\
\text { macrostachyus }\end{array}$ & $44(60 \%)$ & $21(30 \%)$ & $8(10 \%)$ \\
\hline 4 & Cupressus lusitanica & $51(70 \%)$ & 15(20\%) & $8(10 \%)$ \\
\hline 5 & Junipers procera & $55(75 \%)$ & 13(18\%) & $5(7 \%)$ \\
\hline 6 & Olea europeae & $59(81 \%)$ & $6(8 \%)$ & $8(11 \%)$ \\
\hline 7 & Rhamnus prinoides & $6(8 \%)$ & $52(72 \%)$ & $15(20 \%)$ \\
\hline 8 & $\begin{array}{l}\text { Eucalyptus } \\
\text { camaldulensis }\end{array}$ & $54(74 \%)$ & 14(19\%) & $5(7 \%)$ \\
\hline 9 & Eucalyptus globulus & $53(72 \%)$ & $16(22 \%)$ & $4(6 \%)$ \\
\hline
\end{tabular}

Source: Survey results.

TABLE 9 | Opportunities for managing agro-forestry.

\begin{tabular}{llcc}
\hline S/N & Opportunities & $\begin{array}{c}\text { Percent of respondents } \\
(\boldsymbol{n}=\mathbf{7 3 )}\end{array}$ & Rank \\
\hline 1 & Market & $72(98 \%)$ & 1 \\
2 & Water harvesting & $50(68 \%)$ & 4 \\
3 & Tree planting farmers & $53(73 \%)$ & 3 \\
4 & Credit facility & $44(60 \%)$ & 5 \\
5 & Seedling supply & $61(83 \%)$ & 2
\end{tabular}

Source: Survey results.

include water shortage (73\%), lack of polyethene tube (61\%), seed shortage $(77 \%)$, pre sowing treatment $(74 \%)$, knowledge limitations (68\%), pest and disease (5\%) and labour shortage (56\%) (Table 7). These findings compare faily well with those by Chitakira and Torquebiau (2010) in a related study in Zimbabwe, although in the latter case, water and fencing to protect crops were the top-most perceived challenges. Training in the behaviour of some species as regards germination, and in the use of polyethene tubes was suggested as a way to address knowledge limitations. The responsibility of making important tree management decisions was revealed to be largely for the men although in some cases women are also involved (Table 8). 
Farmers often experiment with agro-forestry and innovate on their own account (Poudel, 2018). In many countries, rural people traditionally plant trees for a multiplicity of household uses (Yakob et al., 2014). Respondents in this study had the knowhow of constructing water-harvesting structures as a means of solving the problems of water shortage. The study also revealed the farmers' awareness of tree products and how to market them and the perceived good prices from tree product sales (Table 9). Table 9 shows that a majority (98\%) of the respondents sold their products in the local markets. The other opportunities inlcuded credit facility (60\%), access to tree planting farmers (73\%), construction of water-harvesting structures $(68 \%)$ and seedling supply (83\%). Farmers pointed out that they could get credit locally from Woreda Credit and Saving Institution (WCSI). Understanding such farmers' experiences and meeting farmers' aspirations is important in the scaling-up of agroforestry (Girard, 2015).

\section{CONCLUSION AND RECOMMENDATIONS}

It has been shown that local farmers have accumulated a vast wealth of knowledge for managing agro-forestry over years and which has transferred from one generation to another. In the study, farmers' knowledge about tree-crop and tree-animal interraction was shown to be applicable for improvement of soil fertility, crop yield and animal health. Thus, farmers' knowledge has played a pivotal role in sustaining agro-forestry and food production systems in the study area.

This study therefore recommends the establishment of a centre where local farmers' knowledge is systematically documented and kept, probably at the local government level.

It is seen that farmers' knowledge is the basis for local level decision making for agro-forestry management in the community. So, by documenting the findings it should be possible to apply such local indegenous knowledge in harmony with the contemporary or scientific knowledge. Integrating local farmers' knowledge is important in enhancing the chances of success of development activities. If local knowledge is not documented, it remains largely inaccessible to development workers seeking solutions to locally defined problems. Further research could look into sustainable ways of integrating local farmer's knowledge with

\section{REFERENCES}

Agrawal, A. (1995). Indigenous and scientific knowledge: some critical comments. Indi. Knowl. Dev. Monitor 3, 3-6. doi: 10.7454/ai.v0i55.3331

Alemayehu, F., Taha, N., Nyssen, J., Girma, A., Zenebe, A., Behailu, M., et al. (2009). The impacts of watershed management on land use and land cover dynamics in Eastern Tigray (Ethiopia). Resour. Conserv. Recycling 53, 192-198. doi: 10.1016/j.resconrec.2008.11.007

Arnold, J. M., and Dewees, P. A. (2014). Farms Trees and farmers: Responses to agricultural intensification. London: Routledge. doi: 10.4324/9781315071107

Bishaw, B., Neufeldt, H., Mowo, J., Abdelkadir, A., Muriuki, J., Dalle, G., et al. (2013). Farmers' Strategies for Adapting to and Mitigating Climate Variability and Change Through Agroforestry in Ethiopia and Kenya, eds C. M. Davis, B. scientific knowledge in the context of climate variability and global change.

\section{DATA AVAILABILITY STATEMENT}

The datasets presented in this article are not readily available because Ethical clearance given may not permit sharing of datasets with a third party. Requests to access the datasets may be directed to58550763@mylife.unisa.ac.za.

\section{ETHICS STATEMENT}

The studies involving human participants were reviewed and approved by College of Agriculture and Environmental Science Ethics Review Committee, University of South Africa. The participants provided their written informed consent to participate in this study.

\section{AUTHOR CONTRIBUTIONS}

$\mathrm{YH}$ and MC: project conception. MC: final manuscript. $\mathrm{YH}$, $\mathrm{MC}$, and $\mathrm{KY}$ : draft manuscript. $\mathrm{MC}$ and $\mathrm{KY}$ : quality control and supervision. YH: data collection and analysis. All authors contributed to the article and approved the submitted version.

\section{FUNDING}

The logistical support by the University of South Africa and Wachemo University (particularly office of research and public service) is greatly appreciated.

\section{ACKNOWLEDGMENTS}

Researchers are grateful to the farmers of Masbira, Shecha and Lissana senna PAs in Lemo Woreda who devoted their precious time to share their immense locally adapted knowledge and their experience during the critical crop planting period. Many thanks to the enumerators (Ato Adinaw Baffa, Ato Mengesha Abate, Ato Dereje Lemma, Ato Habte Asirat, Ato Chakisso Wolde and Ato Gizaw Abaka) who assisted in data collection, as well as the staff of Lemo Woreda office of agriculture and natural resources for their unreserved cooperation and support in this study.

Bernart, A. C. Dmitriev. Oregon: Forestry Communications Group; Oregon State University.

Brown, S. E., Miller, D. C., Ordonez, P. J., and Baylis, K. (2018). Evidence for the impacts of agroforestry on agricultural productivity, ecosystem services, and human well-being in high-income countries: a systematic map protocol. Environ. Evid. 7, 1-16. doi: 10.1186/s13750-018-0136-0

Cerdán, C. R., Rebolledo, M. C., Soto, G., Rapidel, B., and Sinclair, F. L. (2012). Local knowledge of impacts of tree cover on ecosystem services in smallholder coffee production systems. Agric. Syst. 110, 119-130 doi: 10.1016/j.agsy.2012.03.014

Cheveau, M., Imbeau, L., Drapeau, P., and Bélanger, L. (2008). Current status and future directions of traditional ecological knowledge in forest management: a review. For. Chron. 84, 231-243. doi: 10.5558/tfc84231-2 
Chitakira, M., and Torquebiau, E. (2010). Barriers and coping mechanisms relating to agroforestry adoption by smallholder farmers in Zimbabwe. J. Agric. Educ. Extension 16, 147-160. doi: 10.1080/13892241003651407

Chowdhury, M. S. H., Halim, M. A., Muhammed, N. U. R., Koike, M., and Biswas, S. (2009). Indigenous knowledge in natural resource management by the hill people: a case of the mro tribe in Bangladesh. For. Trees Livelihoods 19, 129-151. doi: $10.1080 / 14728028.2009 .9752660$

Chuma, E., Mombeshora, B., Murwira, H., and Chikuvire, J. (2000). "The dynamics of soil fertility management in communal areas of Zimbabwe," in Nutrients on the move: Soil fertility dynamics in African farming systems. Chapter 3, eds T. Hilhorst and F. M. Muchena. (London: International Institute for Environment and Development), 45-64.

Dagar, J. C., Singh, A. K., and Arunachalam, A. (eds.). (2013). Agroforestry Systems in India: Livelihood Security \& Ecosystem Services, Vol. 10 (New Delhi: Springer Science \& Business Media). doi: 10.1007/978-81-322-1662-9

Dawoe, E. K., Quashie-Sam, J., Isaac, M. E., and Oppong, S. K. (2012). Exploring farmers' local knowledge and perceptions of soil fertility and management in the Ashanti Region of Ghana. Geoderma 179, 96-103. doi: 10.1016/j.geoderma.2012.02.015

De Groot, R. S., Alkemade, R., Braat, L., Hein, L., and Willemen, L. (2010). Challenges in integrating the concept of ecosystem services and values in landscape planning, management and decision making. Ecol. Complexity 7 , 260-272. doi: 10.1016/j.ecocom.2009.10.006

Elias, E. (2000). "Soil enrichment and depletion in southern Ethiopia," in 2000. Nutrients on the move: Soil fertility dynamics in African farming systems, Chapter 4, eds T. Hilhorst and F. M. Muchena (London: International Institute for Environment and Development), 65-81.

Girard, N. (2015). Knowledge at the boundary between science and society: a review of the use of farmers' knowledge in agricultural development. J. Know. Manage. 19, 949-967. doi: 10.1108/JKM-02-2015-0049

Glover, E. K., Ahmed, H. B., and Glover, M. K. (2013). Analysis of socio-economic conditions influencing adoption of agroforestry practices. Int. J. Agric. For. 3, 178-184. doi: 10.5923/j.ijaf.20130304.09

Goldammer, J. G. (2013). Holm Uibrig'. Tropical Forests in Transition: Ecology of Natural and Anthropogenic Disturbance Processes. Basel: Birkhäuser. 135.

Kidanu, S., Mamo, T., and Stroosnijder, L. (2005). Biomass production of Eucalyptus boundary plantations and their effect on crop productivity on Ethiopian highland Vertisols. Agro-for. Syst. 63, 281-290. doi: 10.1007/s10457-005-5169-z

Kindeya, G. (2004). "Area enclosures as an approach in the management of dry land biodiversity; a case study in Tigray region, northern Ethiopia," in Proceedings of the Work Shop on Management of Dry Land Biodiversity (Nairobi).

Larson, D. F., Muraoka, R., and Otsuka, K. (2016). Why African rural development strategies must depend on small farms. Global Food Secur. 10, 39-51. doi: 10.1016/j.gfs.2016.07.006

Leeuwis, C. (2013). Communication for rural innovation: rethinking agricultural extension. Hoboken, NJ: John Wiley \& Sons.

LWOAaRD (Lemo Woreda Office of Agriculture and Rural Development). (2012). Annual Report. Hawassa: Office of Agriculture and Rural Development.

Meijer, S. S., Catacutan, D., Ajayi, O. C., Sileshi, G. W., and Nieuwenhuis, M. (2015). The role of knowledge, attitudes and perceptions in the uptake of agricultural and agroforestry innovations among smallholder farmers in sub-Saharan Africa. Int. J. Agric. Sustain. 13, 40-54. doi: 10.1080/14735903.2014.912493

Munyua, H. M., and Stilwell, C. (2013). Three ways of knowing: agricultural knowledge systems of small-scale farmers in Africa with reference to Kenya. Libr. Inf. Sci. Res. 35, 326-337. doi: 10.1016/j.lisr.2013.04.005

Musinguzi, P., Ebanyat, P., Tenywa, J. S., Basamba, T. A., Tenywa, M. M., and Mubiru, D. (2015). Precision of farmer-based fertility ratings and soil organic carbon for crop production on a Ferralsol. Solid Earth 6:1063. doi: $10.5194 /$ se-6-1063-2015

Nandwa, S., Onduru, D., and Gachimbi, L. (2000). "Soil fertility regeneration in Kenya," in Nutrients on the Move: Soil Fertility Dynamics in African Farming
Systems, Chapter 7, eds T. Hilhorst and F. M. Muchena (London: International Institute for Environment and Development), 119-132.

Njiraine, D., Onyancha, O. B., and Ocholla, D. N. (2010). Indigenous knowledge research in Kenya and South Africa: an informetric study. Indilinga Afr. J. Indigenous Knowl. Syst. 9, 194-210.

Nyssen, J., Haile, M., Naudts, J., Munro, N., Poesen, J., Moeyersons, J., et al. (2009). Desertification? Northern Ethiopia re-photographed after 140 years. Sci. Tot. Environ. 407, 2749-2755. doi: 10.1016/j.scitotenv.2008.12.016

Payyappallimana, U., and Koike, O. (2010). Traditional knowledge for sustainable development: a case from the health sector in Kerala, India. Glob. Environ. Res. $14,167-175$.

Pirker, H., Haselmair, R., Kuhn, E., Schunko, C., and Vogl, C. R. (2012). Transformation of traditional knowledge of medicinal plants: the case of Tyroleans (Austria) who migrated to Australia, Brazil and Peru. J. Ethnobiol. Ethnomed. 8:44. doi: 10.1186/1746-4269-8-44

Ponge, A. (2013). Integrating Indigenous Knowledge for Food Security: Perspectives from the Millennium Village Project at Bar-Sauri in Nyanza Province in Kenya. Nairobi: African Research and Resource Forum (ARRF)

Poudel, D. P. (2018). Changing Forestry Governance in Nepal Himalaya. Interactions of Community Forestry with REDD+ and Traditional Institution (Doctoral Thesis). Available online at: https://hdl.handle.net/1956/18615. (accessed September 15, 2021).

Rahman, S. A., Sunderland, T., Kshatriya, M., Roshetko, J. M., Pagella, T., and Healey, J. R. (2016). Towards productive landscapes: trade-offs in tree-cover and income across a matrix of smallholder agricultural land-use systems. Land Use Policy 58, 152-164. doi: 10.1016/j.landusepol.2016.07.003

Schroth, G. (1995). Tree root characteristics as criteria for species selection and systems design in agroforestry. Agrofor. Syst. 30, 125-143. doi: 10.1007/978-94-017-0681-0_6

Sjögren, H. (2015). Agro-Forestry Systems With Trees for Biomass Production in Western Kenya, Vol. 2015. (Doctoral Thesis) (Swedish University of Agricultural Sciences), 43. Available online at: https://pub.epsilon.slu.se/ 12165/. (accessed September 15, 2021).

Tafere, S. M., and Nigussie, Z. A. (2018). The adoption of introduced agroforestry innovations: determinants of a high adoption rate-a case-study from Ethiopia. For. Trees Livelihoods 27, 175-194. doi: 10.1080/14728028.2018.14 93954

Tesfaye, A. (2005). Diversity in Homegarden Agroforestry Systems of Southern Ethiopia (PhD thesis). Wageningen University, Wageningen, Netherlands.

Yakob, G., Asfaw, Z., and Zewdie, S. (2014). Wood production and management of woody species in homegardens agroforestry: the case of smallholder farmers in Gimbo district, South West Ethiopia. Int. J. Natl. Sci. Res. $2,165-175$

Yirga, G. (2010). Assessment of indigenous knowledge of medicinal plants in Central Zone of Tigray, Northern Ethiopia. Afr. J. Plant Sci. 4, 006-011. doi: 10.5897/AJPS.9000028

Conflict of Interest: The authors declare that the research was conducted in the absence of any commercial or financial relationships that could be construed as a potential conflict of interest.

Publisher's Note: All claims expressed in this article are solely those of the authors and do not necessarily represent those of their affiliated organizations, or those of the publisher, the editors and the reviewers. Any product that may be evaluated in this article, or claim that may be made by its manufacturer, is not guaranteed or endorsed by the publisher.

Copyright $\odot 2021$ Horamo, Chitakira and Yessoufou. This is an open-access article distributed under the terms of the Creative Commons Attribution License (CC BY). The use, distribution or reproduction in other forums is permitted, provided the original author(s) and the copyright owner(s) are credited and that the original publication in this journal is cited, in accordance with accepted academic practice. No use, distribution or reproduction is permitted which does not comply with these terms. 